\title{
Effects of Early Protein-Calorie Malnutrition on the Immune Response
}

\author{
S. O. OLUSI AND H. MCFARLANE(18
}

Department of Medical Biochemistry, The University of Manchester, Manchester, England

Intrauterine and early postnatal malnutrition caused a marked and protracted weight reduction of the body, spleen, and thymus. The mean body weight of the offspring of the malnourished mothers at weaning was $25 \pm 10 \mathrm{~g}$ whereas that of the controls was $75 \pm 20$ g. At weaning the mean spleen weight of the malnourished of fspring was $0.19 \pm 0.05 \mathrm{~g}$ and that of their controls was $0.4 \pm 0.13 \mathrm{~g}$. During refeeding the spleen weight but not the thymus weight of the malnourished offspring caught up with that of the controls after about $\mathbf{7 0}$ days. After refeeding for as long as $\mathbf{4}$ months the thymus weight of the malnourished was still significantly $(P<0.01)$ less than that of the corresponding weight-matched controls. Primary and secondary plaque-forming cells (PFC) in both the spleen and thymus of the weanling malnourished offspring were barely detectable whereas spleen of their controls had mean approximate values of $50 \times 10^{3}$ primary $\mathrm{PFC}$ and $70 \times 10^{3}$ secondary PFC. The corresponding values in the control thymus were $20 \times 10^{2}$ primary $\mathrm{PFC}$ and $8 \times 10^{2}$ secondary PFC.

After refeeding for 4 months of the weanling malnourished offspring their primary and secondary PFC in the spleen increased to about one-half the level of that in their controls whereas the PFC in the thymus were still barely detectable. On the other hand, mean primary and secondary rosette-forming cells (RFC) in the spleen of the weanling malnourished offspring were less than $1 \times 10^{3}$ in comparison to the $80-90 \times 10^{3}$ in the controls $(P<0.001)$. In the thymus too, mean primary and secondary RFC were also less than $1 \times$ $10^{3}$, whereas the corresponding figure in the controls was $30-50 \times$ $10^{3}$ RFC. After refeeding for 4 months the mean values of both the primary and secondary RFC in the spleen and thymus continued to remain less than $1 \times 10^{3}$.

Although cell morphology in the spleen of the malnourished offspring had returned to normal appearance after 4 months of refeeding, that of the corresponding thymus had not done so completely. For instance, thymic corticomedullary function had reappeared by this time but thymocytes were still less in number than in the controls. By the 8th postnatal day serum IgG2b allotype became detectable in the control offspring, but it was not until day 20 that this IgG allotype could be detected in the malnourished offspring. IgG2a allotype could be detected in the sera of both the malnourished and control offspring.

\section{Speculation}

Impairment of cell-mediated immune response caused by intrauterine and neonatal protein-calorie malnutrition is probably responsible for the skin, oral, and respiratory tract infections seen in children with early protein-calorie malnutrition. Thymic reconstitution might play a significant role in the treatment of these children. This speculation is now being investigated.

Both the humoral and cellular immune responses are depressed in malnutrition. Thus, Gell (5) reported that prisoners of war on a protein-deficient diet had significantly lower antibody titers to both fowl red cells and tobacco mosaic virus than their well-fed control subjects. Jose et al. (7) reported that the antibody response to influenza vaccine of children who were supposed to have had previous protein-calorie deficiency was significantly poorer than control subjects both in magnitude of the antibody rise and in the proportion of children showing a significant rise of antibody titer.

McFarlane et al. (8-10), Smythe et al. (13), Geefhugsen et al. (4), Chandra (2), and Douglas and Schofer (3) all reported impaired cellular immune response in malnutrition. Jose et al. (7) suggested that severe malnutrition in early life may have a long term effect on the immune system. Impairment of the immune response by early protein-calorie malnutrition would obviously have profound effects on immunization programs in communities where both protein-calorie malnutrition and infectious diseases are endemic. As far as we know there are few reports in the literature describing the effects of early protein-calorie malnutrition on the immune response. We describe here the effects of intrauterine and early postnatal protein-calorie malnutrition on the immune response in rats.

\section{MATERIALS AND METHODS}

\section{ANIMALS AND DIET}

Five groups of adult female Sprague-Dawley rats were placed for 7 days on a low protein diet of average grade baker's flour, the composition of which is given in Tables 1 and 2. This diet was chosen because it closely resembles the low protein, high carbohydrate diet of poor communities where protein-calorie malnutrition is endemic. These female rats were then each mated in separate cages with a well nourished adult male rat, until successful mating. as judged by the shedding of the vaginal plug, had taken place. The male rat was then removed and each female rat was kept on the low protein diet until it littered. The newborn rats were allowed to suckle from their malnourished mothers until weaning. Some of the young rats were then killed for the analysis of their immune response while the rest were weaned onto the low protein diet. They were maintained on this diet for another 21 days after which some more of the animals were killed. The remaining animals were then refed with normal mouse cube high protein diet for a period of 4 months, at the end of which they were killed for the analysis of their immune response. The composition of the mouse cube diet is given in Table 1.

Five groups of control female Sprague-Dawley rats on normal mouse cube high protein diet were also subjected to the same experimental design as above. Table 3 summarizes the experimental designs.

\section{ANTISERA TO RAT PROTEINS}

Antisera to rat transferrin, complement C3, $\alpha_{2}$-macroglobulin, and $\operatorname{IgG}$ were purchased from Microbiological Associates, Bethesda, Md. and from Miles Laboratories, Inc., London. Antiserum to rat albumin was prepared by us and its monospecificity exhaustively tested. 


\section{ASSESSMENT OF NUTRITIONAL STATUS}

This was done by both anthropometric measurements (body and organ weights) and biochemical estimations (serum transferrin, complement C3, albumin).

\section{MEASUREMENT OF IMMUNE RESPONSE}

Intraperitoneal injections $(0.2 \mathrm{ml})$ of $40 \%$ washed sheep red blood cells were made into each animal at the appropriate intervals. Their immune responses were assessed by measuring the number of PFC, i.e., antibody-producing cells, and the number of RFC, i.e., antigen-binding cells, according to the method described in our previous publication (9). The rats were killed on day 5, and the peak of the primary immune response and the PFC and RFC were determined.

Table 1. Comparative composition of rat diets

\begin{tabular}{|c|c|c|}
\hline & $\begin{array}{l}\text { Average grade } \\
\text { baker's flour }\end{array}$ & Mouse cubes \\
\hline Protein & $\begin{array}{l}(n \times 5.7) 11.5 \mathrm{~g} / \\
100 \mathrm{~g}\end{array}$ & $(n \times 6.2) 20 \mathrm{~g} / 110 \mathrm{~g}$ \\
\hline Carbohydrate & $74.0 \mathrm{~g} / 100 \mathrm{~g}$ & $68.0 \mathrm{~g} / 100 \mathrm{~g}$ \\
\hline Fat & $1.5 \mathrm{~g} / 100 \mathrm{~g}$ & $3.0 \mathrm{~g} / 100 \mathrm{~g}$ \\
\hline \multicolumn{3}{|l|}{ Vitamins } \\
\hline Thiamine & $0.24 \mathrm{mg} / 100 \mathrm{~g}$ & $0.05 \mathrm{mg} / 100 \mathrm{~g}$ \\
\hline $\mathrm{B}_{2}$ (riboflavin) & $0.0 \mathrm{mg} / 100 \mathrm{~g}$ & $1.50 \mathrm{~g} / 100 \mathrm{~g}$ \\
\hline $\mathrm{B}_{6}$ (pyridoxine, etc.) & $0.10 \mathrm{mg} / 100 \mathrm{~g}$ & Naturally occurring \\
\hline $\mathrm{B}_{12}($ cobalamin $)$ & $0.0 \mathrm{mg} / 100 \mathrm{~g}$ & $0.34 \mathrm{mg} / 100 \mathrm{~g}$ \\
\hline Niacin (nicotinic acid) & $1.6 \mathrm{mg} / 100 \mathrm{~g}$ & Naturally occurring \\
\hline Pantolthinic acid & 1 & Naturally occurring \\
\hline Biotin & 0.5 & Naturally occurring \\
\hline Folic acid & 7.0 & Naturally occurring \\
\hline Vitamin A & 1 & $39.281 . \mu / 100 \mathrm{~g}$ \\
\hline Vitamin D & 1 & $90.21 . \mu / 100 \mathrm{~g}$ \\
\hline Vitamin E & 1 & $0.12 \mathrm{mg} / 100 \mathrm{~g}$ \\
\hline Vitamin $\mathrm{K}^{2}$ & 1 & $0.05 \mathrm{mg} / 100 \mathrm{~g}$ \\
\hline Iron & $1.65 \mathrm{mg} / 100 \mathrm{~g}$ & 3 \\
\hline Calcium carbonate & $300 \mathrm{mg} / 100 \mathrm{~g}$ & \\
\hline Magnesium & $34.1 \mathrm{mg} / 100 \mathrm{~g}$ & \\
\hline Copper & $0.17 \mathrm{mg} / 100 \mathrm{~g}$ & \\
\hline Sodium & $2.2 \mathrm{mg} / 100 \mathrm{~g}$ & \\
\hline Potassium & $82.0 \mathrm{mg} / 100 \mathrm{~g}$ & \\
\hline Chloride & $47.8 \mathrm{mg} / 100 \mathrm{~g}$ & \\
\hline
\end{tabular}

${ }^{1}$ No estimations have been made.

${ }^{2}$ Known to be synthesized by the rat.

${ }^{3}$ All of the known trace metals are added in bulk quantity at a concentration of 5 pounds/ton.
ESTIMATION OF SERUM PROTEIN CONCENTRATIONS

The serum concentrations of transferrin, complement C3, albumin, $\alpha_{2}$-macroglobulin, and $\operatorname{IgG}$ were determined immunochemically using the technique of Mancini et al. (11). The automated immunonephelometry assay method of Olusi et al. (12) was also used for transferrin and IgG determination.

\section{QUALITATIVE DETECTION OF IgG ALLOTYPES IN SERUM}

Immunoelectrophoresis was carried out according to the method of Grabar and Burtin.

IgG separation was also carried out by means of ion exchange chromatography using DE-52 (Whatman, U.K.) with the following elution buffers: $0.01 \mathrm{M}$ phosphate $(\mathrm{pH} 7.5), 0.1 \mathrm{M}$ phosphate buffer ( $\mathrm{pH} 6.2$ ), and $0.3 \mathrm{M}$ phosphate buffer $(\mathrm{pH} 4.8)$.

\section{HISTOLOGY}

Portions of the thymus and spleen were fixed in $10 \%$ buffered formalin at $\mathrm{pH} 7.0$, embedded in paraffin, and sectioned at $7 \mu \mathrm{m}$. Sections were stained with hematoxylin and eosin.

Table 2. Concentration of amino acids (grams) per $g$ nitrogen of the various diets ${ }^{1}$

\begin{tabular}{lccc}
\hline Amino acids & $\begin{array}{c}\text { Flour, } \\
70-75 \% \text { ext }\end{array}$ & Meat & Fish \\
\hline Arg & 0.23 & 0.41 & 0.36 \\
Cyst & 0.13 & 0.08 & 0.07 \\
Hist & 0.13 & 0.20 & 0.13 \\
Ileu & 0.24 & 0.32 & 0.32 \\
Leu & 0.43 & 0.49 & 0.47 \\
Lys & 0.13 & 0.51 & 0.56 \\
Met & 0.10 & 0.15 & 0.18 \\
Phe & 0.32 & 0.32 & 0.23 \\
Thr & 0.18 & 0.28 & 0.28 \\
Try & 0.06 & 0.08 & 0.06 \\
Tyr & 0.20 & 0.21 & 0.19 \\
Val & 0.29 & 0.33 & 0.33 \\
Ala & & & \\
Asp & 0.17 & 0.39 & 0.38 \\
Glu & 0.26 & 0.57 & 0.59 \\
Gly & 2.10 & 0.96 & 0.88 \\
Pro & 0.21 & 0.28 & 0.38 \\
Ser & 0.72 & 0.27 & 0.37 \\
& 0.30 & 0.26 & 0.33 \\
\hline
\end{tabular}

${ }^{1}$ Note the low content of lysine in the flour diet. The amino acid content of meat and fish are given as these are the chief protein in the mouse cubes. The horizontal division in the table separates the essential from the nonessential amino acids (8).

Table 3. Effects of maternal malnutrition on reproduction

\begin{tabular}{|c|c|c|c|c|c|}
\hline Animal group & $\begin{array}{c}\text { No. of females } \\
\text { time-mated }\end{array}$ & $\begin{array}{c}\text { No. of females } \\
\text { pregnant }\end{array}$ & $\begin{array}{l}\text { Average no. } \\
\text { of young/litter }\end{array}$ & $\begin{array}{c}\text { Average } \\
\text { fetal weight, } g\end{array}$ & $\begin{array}{l}\text { Mean change } \\
\text { in maternal } \\
\text { body weight, } \mathrm{g}^{1}\end{array}$ \\
\hline Control group I & 4 & 4 & 12 & $6 \pm 0.5$ & 30 \\
\hline Control group II & 5 & 5 & 10 & $6.5 \pm 0.6$ & 35 \\
\hline Control group III & 3 & 3 & 11 & $7.0 \pm 0.8$ & 36 \\
\hline Control group IV & 5 & 5 & 10 & $6.4 \pm 0.5$ & 40 \\
\hline Control group $V$ & 4 & 4 & 9 & $7.5 \pm 0.7$ & 38 \\
\hline Malnourished group I & 4 & 2 & 6 & $4.0 \pm 0.3$ & -15 \\
\hline Malnourished group II & 5 & 2 & 4 & $4.5 \pm 0.4$ & -10 \\
\hline Malnourished group III & 3 & 1 & 6 & $3.8 \pm 0.4$ & -15 \\
\hline Malnourished group IV & 5 & 2 & 2 & $6.0 \pm 0.5$ & -12 \\
\hline Malnourished group $V$ & 4 & 2 & 4 & $5.1 \pm 0.6$ & -8.5 \\
\hline
\end{tabular}

\footnotetext{
${ }^{1}$ Mean change in maternal body weight indicates weight after delivery minus the initial body weight before mating.
} 


\section{RESULTS}

\section{EFFECTS OF MATERNAL MALNUTRITION ON REPRODUCTION}

Table 3 summarizes the results of the effects of maternal malnutrition on reproduction. The pregnancy rate, the average number of young per litter, and the average birth weight were significantly reduced in the malnourished mothers when compared with well-nourished control mothers. The loss in body weight of the malnourished mothers in spite of pregnancy indicated that this group of rats was indeed malnourished.

Changes in Body Weight. As shown in Table 4, the average body weight of the offspring of the malnourished mothers at weaning was $25 \pm 10 \mathrm{~g}$ whereas that of the control offspring was $75 \pm 20 \mathrm{~g}$. When the offspring of the malnourished mothers had been kept on the low protein diet for 21 days after weaning, their body weight was still $25 \pm 10 \mathrm{~g}$. During refeeding, the malnourished offspring gained weight rapidly at first and by the end of 4 months on this improved diet, their average body weight was $250 \pm 30.2 \mathrm{~g}$ whereas the average body weight of the control offspring was $380 \pm 35.3 \mathrm{~g}$ (Fig. 1). Thus it would appear that intrauterine and early postnatal malnutrition in rats resulted in a prolonged decrease in body weight.

Changes in Organ Weights. Table 4 summarizes the effects of intrauterine and early postnatal malnutrition on the weights of the various organs. The brain and the thymolymphatic system were the most severely affected. Thus, at weaning, the brain weight of the malnourished offspring was $0.935 \pm 0.3 \mathrm{~g}$ whereas the brain weight of the offspring of the well nourished mother was $1.41 \pm 0.5$

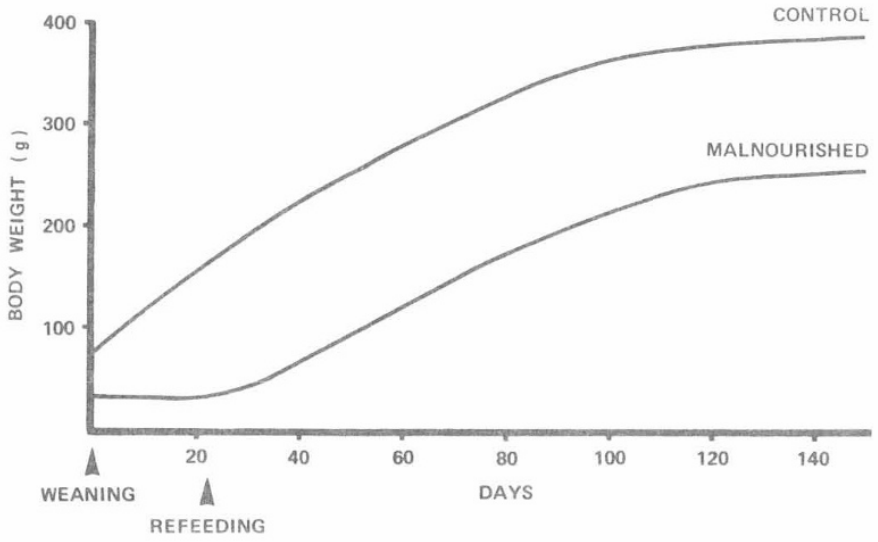

Fig. 1. A typical body weight chart of the offspring from control and malnourished mothers at weaning and during refeeding. The control mothers were fed on a high protein diet throughout and the offspring were weaned onto the same diet. The malnourished mothers were fed on a diet of flour during pregnancy and for 21 days after littering and the offspring were weaned onto the flour diet for another 21 days before they were refed with the high protein diet. g. After refeeding for 4 months, the brain weight of the malnourished offspring was still significantly less than the brain weight of a weight-matched control offspring.

At weaning the mean spleen weight of the malnourished offspring was $0.19 \pm 0.05 \mathrm{~g}$ whereas that of the control offspring was $0.4 \pm 0.13 \mathrm{~g}$. During refeeding, the spleen weight of the malnourished offspring caught up with that of the control after about 70 days (Fig. 2).

Thymus. As shown in Table 4 the mean thymus weight of the malnourished offspring at weaning was $0.13 \pm 0.06 \mathrm{~g}$ whereas that of the control was $0.45 \pm 0.12 \mathrm{~g}$. After refeeding for 4 months the thymus weight of the malnourished offspring was still significantly $(P<0.01)$ less than that of a corresponding weight-matched control.

\section{CHANGES IN IMMUNE RESPONSE}

PFC in Spleen. The marked reduction in the number of PFC in the spleen of the weaning malnourished offspring during the primary and secondary immune response is shown in Figure 3. It could be seen that there was no peak period for PFC in the malnourished rats during either the primary or secondary immune response. After refeeding the number of antibody-producing cells in the spleen gradually increased but at the end of 4 months of refeeding this number was still significantly less than that of control offspring (Fig. 4). Furthermore, as shown in Figure 4, although the primary response of the spleen returned to normal after refeeding, the secondary response was still impaired.

$P F C$ in Thymus. Figure 3 shows the marked reduction in the number of PFC in the thymus of the malnourished offspring. The number of PFC was still profoundly reduced after refeeding for 4 months (Fig. 4). Thus it would appear that early malnutrition causes a prolonged impairment of PFC in the thymus.

$R F C$ in Spleen. As shown in Figure 5 the number of RFC in the

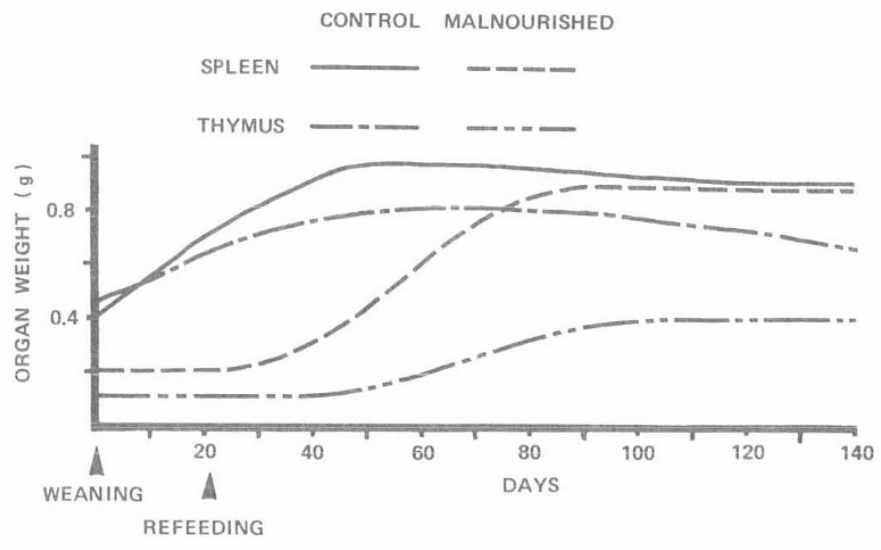

Fig. 2. Organ weights of control and malnourished offspring at weaning and during refeeding.

Table 4. Effects of intrauterine and postnatal malnutrition on body and organ weights

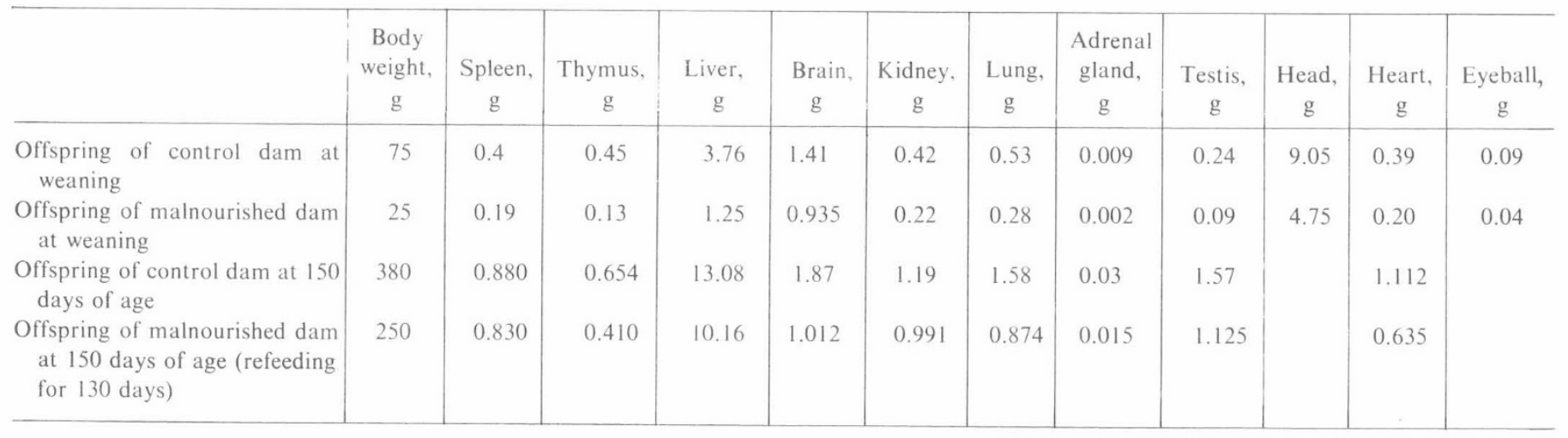



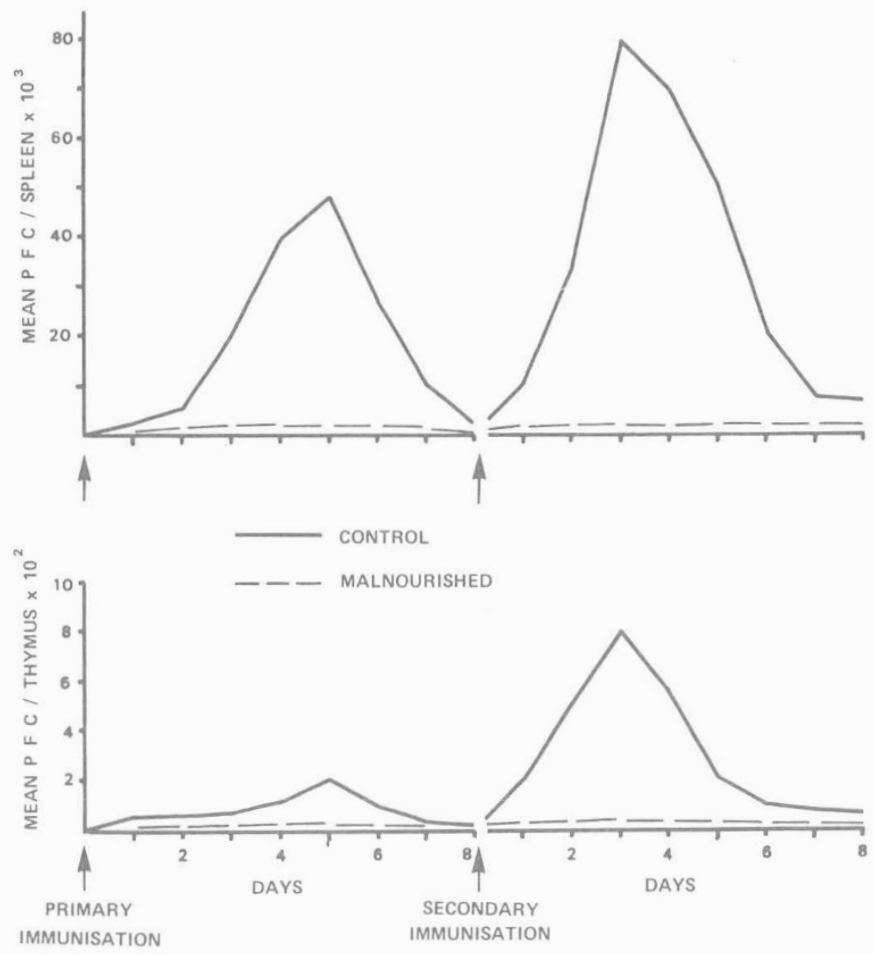

Fig. 3. Primary and secondary humoral immune responses of weanling control $(-)$ and weanling malnourished $(--)$ rats to sheep red blood cells as measured by the number of plaque-forming cells $(P F C)$ in the spleen and thymus.
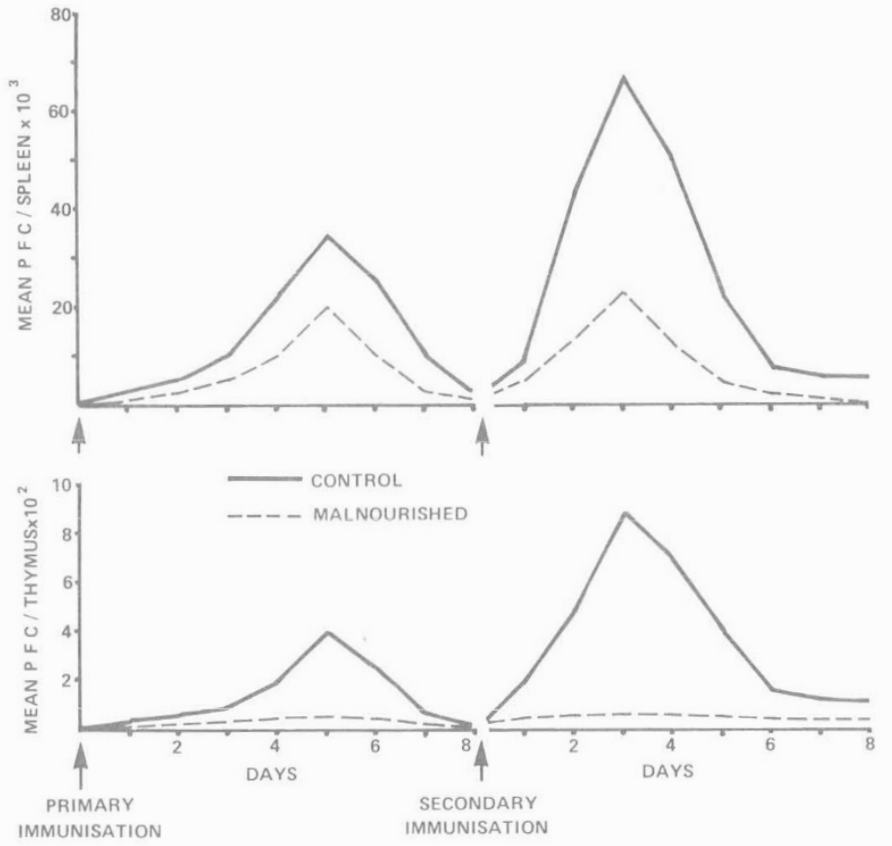

Fig. 4. Primary and secondary humoral immune responses of control and malnourished offspring (that have been refed for 140 days) to sheep red blood cell as measured by the number of plaque-forming cells (PFC). Note that in the spleen, the primary response has returned almost to normal whereas the secondary response is still markedly reduced. Both the primary and secondary responses are still markedly diminished in the thymus.

spleen during the primary and secondary immune response in weaning malnourished offspring was significantly reduced $(P<$ $0.001)$. After refeeding for 4 months the number of RFC in the spleen of the malnourished offspring was still significantly $(P<$
$0.001)$ less than that of the control both during the primary and secondary immune response (Fig. 6). Thus it would appear that intrauterine and early postnatal malnutrition causes a prolonged impairment of RFC but not of PFC in the spleen.

$R F C$ in Thymus. There was a significant depression $(P<0.001)$ in the number of RFC in the thymus of the malnourished offspring when compared with that of control offspring. This was not restored by refeeding for 4 months (Fig. 6).

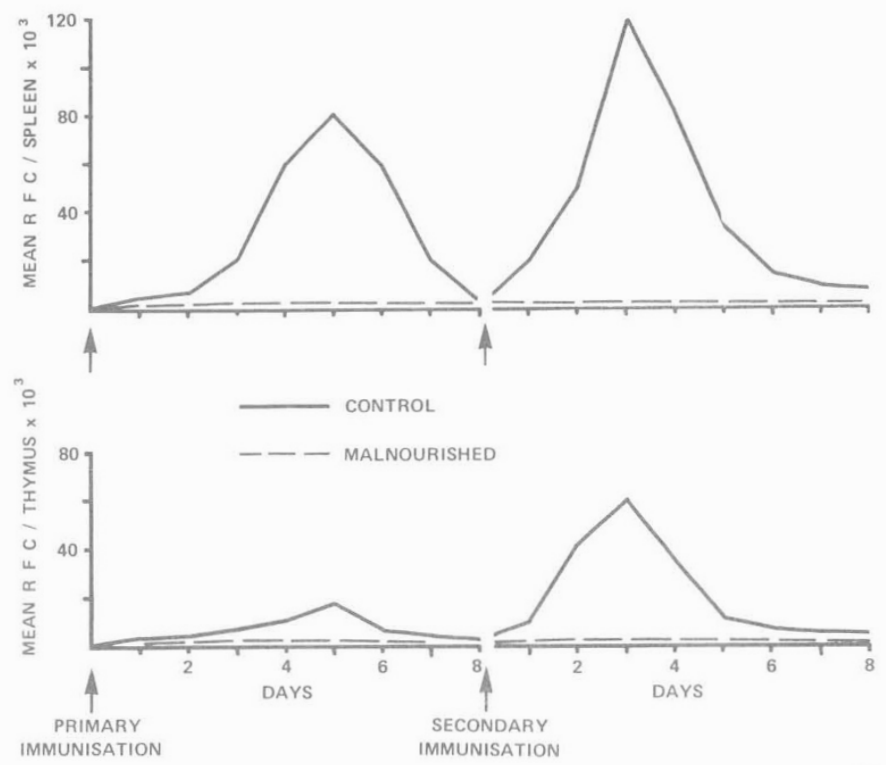

Fig. 5. Primary and secondary cell-mediated immune responses of weanling control $(-)$ and weanling malnourished rats $(--)$ to sheep red blood cells as measured by the number of rosette-forming cells $(R F C)$ in the spleen and thymus. Note the markedly diminished cell-mediated immune responses in the malnourished animals.
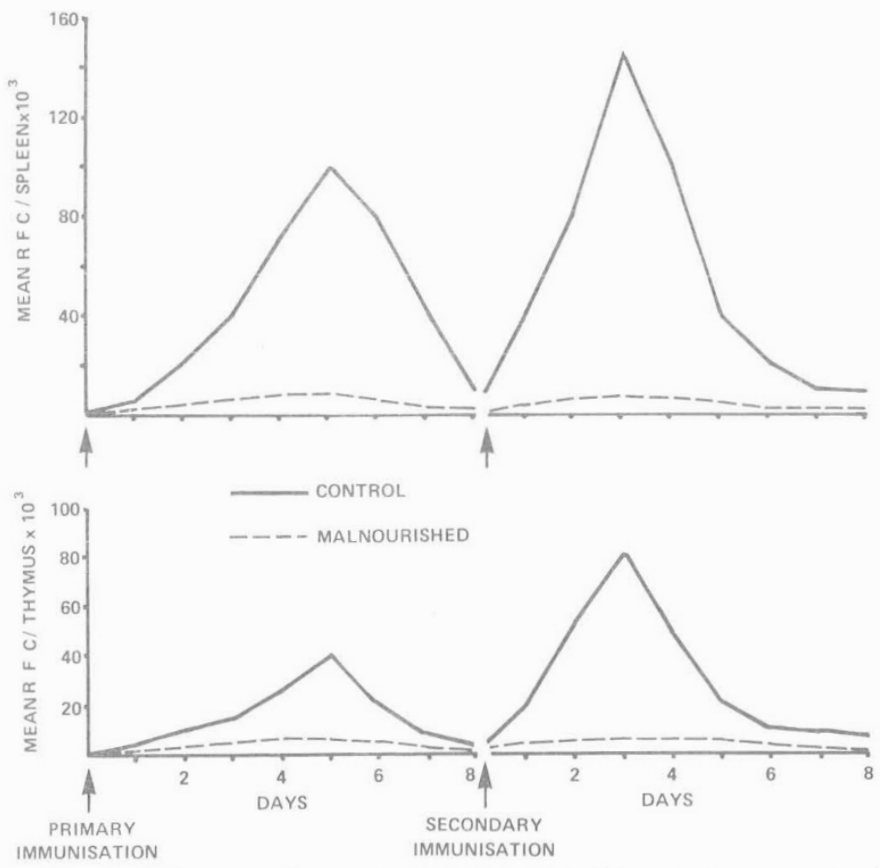

Fig. 6. Primary and secondary cell-mediated immune responses of control (_- ) and refed malnourished rats (- - ) to sheep red blood cells as measured by the number of rosette-forming cells $(R F C)$ in the spleen and thymus. Note that both the primary and secondary cell-mediated immune responses are still markedly diminished in the spleen and thymus even after refeeding for 140 days. 
HISTOLOGIC CHANGES

Thymus. At weaning, the thymus from the malnourished offspring showed profound histologic changes. There was loss of the corticomedullary junction, probably because of the complete loss of the cortex. There were few Hassal's corpuscles and lymphocytes. By the end of 21 days on the low protein diet, these histologic changes became more profound and there appeared to be some fragmentation of Hassal's corpuscles. After refeeding for 4 months, although the corticomedullary junction had appeared, the number of Hassal's corpuscles and of lymphocytes was still reduced. Furthermore, the Hassal's corpuscles still appeared to be fragmented.

Spleen. There was a marked reduction in the size of the germinal centers and in the number of lymphocytes in the spleen of the malnourished offspring (Fig. 7). However, unlike the thymus, the histology of the spleen in the malnourished offspring was restored by refeeding for 4 months.

\section{CHANGES IN IgG ALLOTYPES}

At birth only $\operatorname{IgG}_{2}$ a allotype could be detected in the sera of both the malnourished and control offspring. No $\operatorname{IgG}_{2} \mathrm{~b}$ could be
Table 5. Effects of intrauterine malnutrition on serum concentrations of $\operatorname{IgG}$ allotvpes

\begin{tabular}{|c|c|c|c|c|}
\hline $\begin{array}{l}\text { Day } \\
\text { (post- } \\
\text { natal) }\end{array}$ & $\begin{array}{c}\mathrm{IgG}_{2} \mathrm{a} \\
\text { concen- } \\
\text { tration, \% }\end{array}$ & $\begin{array}{l}\mathrm{IgG}_{2} \mathrm{~b} \\
\text { concen- } \\
\text { tration, \% }\end{array}$ & $\begin{array}{c}\mathrm{IgG}_{2} \mathrm{a} \\
\text { concen- } \\
\text { tration, \% }\end{array}$ & $\begin{array}{c}\mathrm{IgG}_{2} \mathrm{~b} \\
\text { concen- } \\
\text { tration, \% }\end{array}$ \\
\hline 0 & 98.3 & $\begin{array}{c}\text { Not } \\
\text { detectable }\end{array}$ & 90.7 & $\begin{array}{c}\text { Not } \\
\text { detectable }\end{array}$ \\
\hline 4 & 90.6 & $\begin{array}{c}\text { Not } \\
\text { detectable }\end{array}$ & 83.5 & $\begin{array}{c}\text { Not } \\
\text { detectable }\end{array}$ \\
\hline 8 & 81.2 & 39.6 & 77.1 & $\begin{array}{c}\text { Not } \\
\text { detectable }\end{array}$ \\
\hline 12 & 65.1 & 58.7 & 63.6 & $\begin{array}{c}\text { Not } \\
\text { detectable }\end{array}$ \\
\hline 16 & 73.8 & 60.8 & 60.7 & $\begin{array}{c}\text { Not } \\
\text { detectable }\end{array}$ \\
\hline 20 & 78.9 & 70.1 & 59.3 & 36.3 \\
\hline 24 & 83.6 & 77.1 & 60.4 & 40.1 \\
\hline
\end{tabular}

${ }^{1}$ The serum concentrations of both IgG allotypes are expressed as percentages of a standard adult rat reference serum.
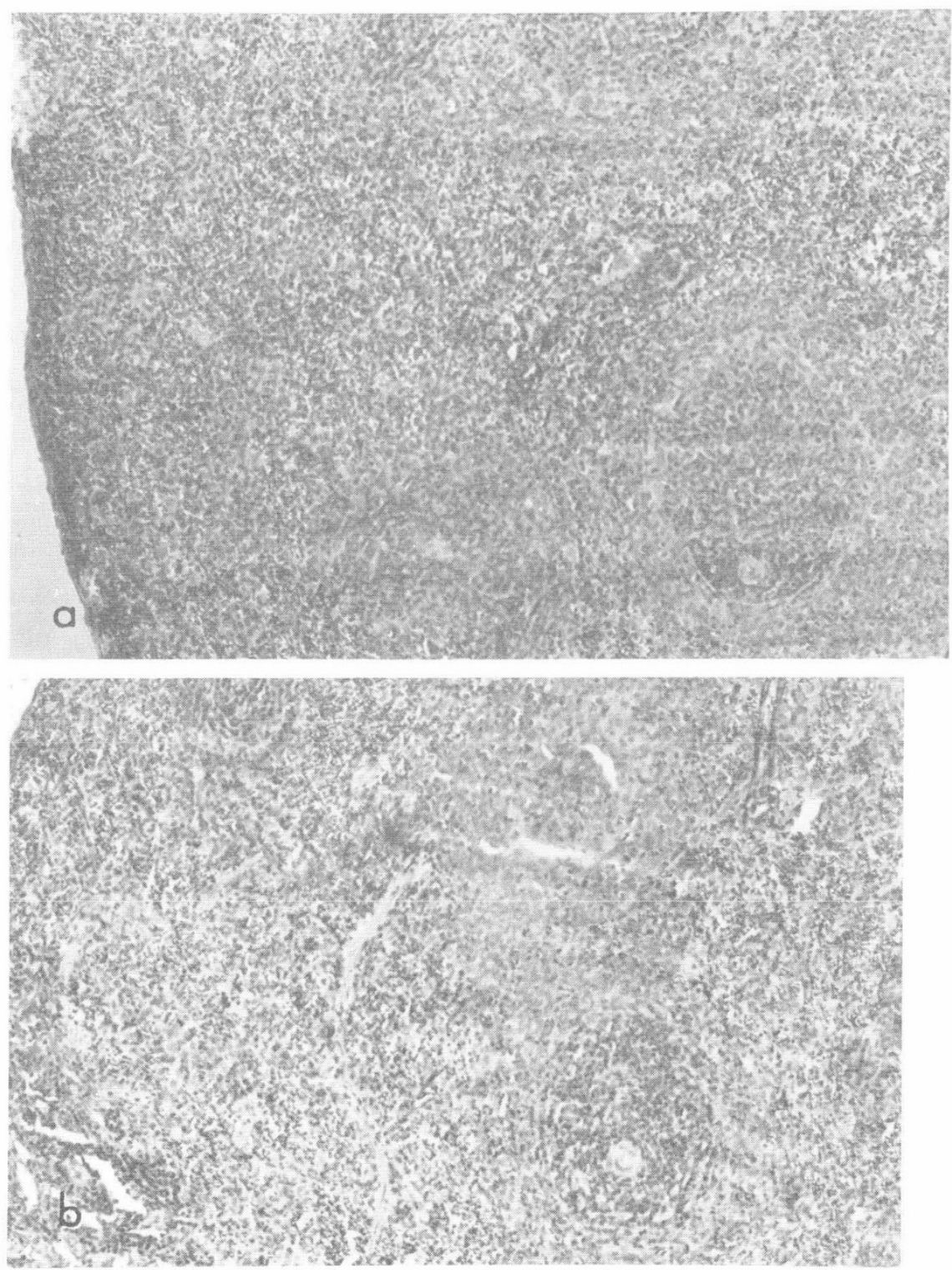

Fig. 7. $a$ : histologic appearance of the spleen of control rat. Note the big germinal center. $b$ : Histologic appearance of the spleen of malnourished rat. Note the small germinal center. 
detected. However, by the 8 th postnatal day, $\operatorname{IgG}_{2}$ b allotype became detectable by double immunodiffusion in the sera of the normal control offspring. On the other hand, $\operatorname{IgG}_{2}$ b allotype could not be detected in the sera of the malnourished offspring until day 20 (Table 5). Furthermore, the concentrations of both IgG allotypes were significantly $(P<0.001)$ higher in control of fspring than in malnourished offspring. It would thus appear that only $\mathrm{IgG}_{2} \mathrm{a}$ crosses the placenta in the rat and that intrauterine malnutrition causes a delay in $\operatorname{IgG}$ synthesis. After refeeding for 4 months, the IgG concentration in the offspring in the malnourished dam was only slightly less than that in the offspring of the control dam.

\section{CHANGES IN ALBUMIN, TRANSFERRIN, AND C3 CONCENTRATIONS}

The serum concentrations of these proteins were significantly $(P$ $<0.05)$ lower in the malnourished offspring than in normal control offspring. After refeeding for 4 months the serum concentrations of these proteins returned to normal.

\section{DISCUSSION}

Our results suggest that intrauterine and early postnatal malnutrition produces severe morphologic changes in the thymolymphatic organs and that although these changes in the spleen could be corrected by refeeding, those in the thymus were more prolonged. These observations support the findings of Hammar (6), who suggested that the thymus was the most critical barometer of malnutrition. Both intrauterine and early postnatal malnutrition produced severe defects in the primary and secondary humoral immune responses as measured by the number of PFC in the spleen. Although the reduction in the primary immune response could be corrected by refeeding for 4 months, that of the secondary response could not. This study would appear to suggest that intrauterine and early postnatal malnutrition may result in a prolonged impairment of the secondary immune response. These results may help to explain the unsuccessful immunizations sometimes observed in some children with infantile malnutrition. The prolonged impairment of the immune response by intrauterine and early postnatal malnutrition is likely to be the result of early severe damage to the thymus. This damage to the thymus could explain the high incidence of skin, oral, and respiratory tract infections in children with protein-calorie malnutrition. It is significant to note that although intrauterine and early postnatal malnutrition produce prolonged impairment of the immune response, malnutrition after weaning produces reversible impairment of the immune response.

$\mathrm{IgG}_{2} \mathrm{~b}$ allotype does not cross the placenta in the rat, whereas $\mathrm{IgGa}$ readily crosses the placenta. This is unlike the situation in man, where all four subclasses of $\operatorname{lgG}$ cross the placenta although $\mathrm{IgG}_{2}$ and $\mathrm{IgG}_{4}$ have a slightly less efficient transfer than $\operatorname{IgG}_{1}$ and $\operatorname{IgG}_{3}(14,15)$.

Unlike malnutrition in the adult rat in which the serum $\operatorname{IgG}$ concentration remains unaffected, intrauterine malnutrition produces marked changes in the serum !gG. Aref et al. (1) found that Egyptian children with kwashiorkor whose clinical disease became apparent before 7 months of age had a regular long delayed and deficient development of serum $\operatorname{IgG}, \operatorname{IgA}$, and $\operatorname{IgM}$; however, older children who presented with their disease at 18-48 months had raised serum $\operatorname{lgG}$, lower than normal $\operatorname{IgM}$, and variable concentrations of $\operatorname{IgA}$, implying that severe malnutrition very early in infancy may be associated with a profound depression of total serum immunoglobulin levels.

\section{SUMMARY}

Intrauterine and early postnatal malnutrition produced in rats prolonged morphologic changes in the thymus but reversible changes in the spleen. There was also a severe depression of both the primary and secondary humoral immune responses as measured by the number of plaque-forming cells. Although the impairment in the primary humoral response was reversible by refeeding for 4 months, the impairment in the secondary humoral response was extensively prolonged and might even be permanent. The humoral immune response of the thymus was far more severely affected than that of the spleen. Both the primary and secondary cell-mediated immune responses, as measured by the number of rosette-forming cells, were irreversibly impaired by intrauterine malnutrition. Thus it would appear that intrauterine malnutrition affects the cell-mediated immune response more than it affects the humoral response and that, although the humoral response could be restored by refeeding, the cell-mediated immune response could not be restored by refeeding. The significance of this as an important factor in skin, oral, and respiratory tract infections in children with protein-calorie malnutrition should not be overlooked.

Unlike late postnatal malnutrition in which IgG concentration is normal, intrauterine and early postnatal malnutrition caused a marked prolonged decrease in $\operatorname{IgG}$ synthesis and in the production of antibodies against specific antigens. This observation is of great significance in planning immunization programs in communities where infantile protein-calorie malnutrition and infectious diseases are endemic.

\section{REFERENCES AND NOTES}

1. Aref, G. H., Badrel Din, M. K., Hassan, A. I., and Araby, 1. I.: Immunoglobulins in kwashiorkor. J. Trop. Med. Hyg., 73: 186 (1970).

2. Chandra, R. K.: Immunocompetence in undernutrition. J. Paediat., 81: 1194 (1972).

3. Douglas, S. D., and Schofer, O. O.: Phagocyte function in protein-calorie malnutrition. Clin. Exp. Immunol., 17: 121 (1974).

4. Geefhuysen, J., Rusen, E. U., Katz, J., Ipp, T., and Metz, J.: Impaired cellular immunity in kwashiorkor with improvement after therapy. Brit. Med. J., 4: 527 (1971).

5. Gell, P. G. H.: In: Studies in undernutrition, Wuppertal (1946-1949). Med. Res. Counc. (Gt. Brit.) Spec. Rep. Ser., 275: 193 (1945).

6. Hammar, J. A.: Zur Histogenese und Involution de Thymosudruse. Anat. Anz., 27: 23 (1905).

7. Jose, D. G., Welch, J. S., and Doherty, R.: Humoral and cellular immune responses to streptococci, influenza and other antigens in Australian aboriginal school children. Aust. Paediat. J., 6: 192 (1970).

8. McFarlane, H.: Cell-mediated immunity in protein-calorie malnutrition. Lancet, ii: 1146 (1971).

9. McFarlane, H., and Hamid, J.: Cell-mediated immune response in malnutrition. Clin. Exp. Immunol., 13: 153 (1973).

10. McFarlane, H., Reddy, S., Adcock, K. J., Adesina, H., Cooke, A., and Akene, J.: Immunity, transferrin and survival in kwashiorkor. Brit. Med. J., 4: 268 (1970).

11. Mancini, G., Carbonara, A. O, and Heremans, J. F.: Immunochemical quantitation of antigens by single radial immunodiffusion. Immunochemistry, 2: 235 (1965).

12. Olusi, S. O., McFarlane, H., Osunkoya, B. O., and Adesina, H. A.: Specific protein assays in protein-calorie malnutrition. Clin. Chim. Acta, 62: $i, 107$ (1975).

13. Smythe, P. M., Schonlan, M., Breveton-Stilles, G. G., Coovadia, H. M., Grace, H. J., Loening, W. E. K., and Mafoyame, A.: Thymolymphatic deficiency and depression of cell-mediated immunity in protein-calorie malnutrition. Lancet, ii: 939 (1971)

14. Virella, G., Nunes, A. S., and Tamagini, G.: Placental transfer of human IgG subclasses. Clin. Exp. Immunol., 10: 475 (1972).

15. Wang, A. C., Faulk, W. P., Stuckley, M. A., and Fudenberg, H. H.: Chemical differences of adult, foetal and hypogammaglobulinaemic IgG immunoglobulins. Immunochemistry, 7: 703 (1970).

16. In conducting the research described in this report the investigations followed the guidelines as laid down by the British Home Office Cruelty to Animals Act, 1876. The facilities which we used for the experimental work are fully accredited by the British Home Office.

17. Dr. S. O. Olusi was supported by the University of Ife, Nigeria, which also provided some funds for this work.

18. Requests for reprints should be addressed to: H. McFarlane, M.D., Department of Medical Biochemistry, University of Manchester, Medical School, Stopford Building, Oxford Rd., Manchester, M13 9PT (England).

19. Accepted for publication February 17, 1976. 